\title{
DAYA SAING BISNIS PT PESONA DAUN MAS ASRI BERDASARKAN AKTIVITAS RANTAI NILAI
}

\author{
BUSINESS COMPETITIVENESS OF PT PESONA DAUN MAS ASRI BASED \\ ON ITS VALUE CHAIN ACTIVITY
}

\author{
Rangga Wisanggara*)1, Muhammad Firdaus $^{* *}$ dan Rina Oktaviani**) \\ *) PT Niro Ceramic Nasional Indonesia \\ Jl. Raya Mercedes, Cicadas, Gunung Putri, Cicadas, Gn. Putri, Bogor, Jawa Barat 16964 \\ ${ }^{* *}$ Departemen Ilmu Ekonomi, Fakultas Ekonomi dan Manajemen, Institut Pertanian Bogor \\ Jl. Agatis Kampus IPB Darmaga, Bogor 16680
}

\begin{abstract}
In 2015, the sales of PT Pesona Daun Mas Asri (PDMA) declined and presumably it was due to the competition in floriculture business. Value Chain Analysis can be used as an approach to assemble strategies and to understand the factors which affect the competitive advantages. This journal aims to map the market power of PT PDMA by analyzing the value chain of its product. The results show that the sales of floriculture in PT PDMA are affected by its five main products including Phillodendrom Marble, Phillodendrom Selloum, Asparagus Myriocladus, Gerbera and Celosia. The declines in the sales of PT PDMA are due to the external and internal factors. As analyzed, PT PDMA has low points in marketing and production but high points in price compared to its competitors.
\end{abstract}

Keywords: floriculture, sales, value chain, PT PDMA, competitive

\begin{abstract}
Abstrak: Pesona Daun Mas Asri (PT PDMA) pada tahun 2015 mengalami penurunan penjualan. Penurunan penjualan tersebut diduga akibat dari persaingan bisnis tanaman hias semakin meningkat. Tujuan dari jurnal ini adalah mengambarkan keadan umum penjualan PT PDMA dan menganalisis rantai nilai tanaman hias di PT PDMA. Analisis rantai nilai digunakan sebagai pendekatan dalam menyusun strategi, membantu pemahaman mengenai faktor-faktor yang memengaruhi keunggulan kompetitif. Hasil analisis didapatkan bahwa hasil penjualan tanaman hias oleh PT PDMA dipengaruhi oleh lima produk unggulan, yaitu Phillodendron marble, Phillodendron selloum, Asparagus bintang, gerbera, dan celosia. Secara keseluruhan trend penjualan tanaman hias PT PDMA mengalami penurunan yang disebabkan oleh faktor eksternal maupun internal perusahaan. Analisis rantai nilai tanaman hias di PT PDMA dapat disimpulkan bahwa masalah utama yang dihadapi oleh PT PDMA adalah pada proses produksi dan pemasaran. PT PDMA memiliki keunggulan harga jika dibandingkan dengan pesaingnya.
\end{abstract}

Kata kunci: tanaman hias, penjualaan, rantai nilai, PT PDMA, daya saing

\footnotetext{
${ }^{1}$ Corresponding author:

Email: ranggawisanggara@gmail.com
} 


\section{PENDAHULUAN}

Masyarakat Ekonomi ASEAN yang telah diberlakukan pada akhir 2015 lalu tidak hanya menghadirkan peluang yang sangat luas untuk memperbesar cakupan bisnis bagi para pelaku dunia usaha di Indonesia, namun turut juga membawa tantangan yang sangat besar, dimana para pelaku usaha Negara-negara ASEAN lainnya akan memasuki pasar di Indonesia. Hal ini akan membuat persaingan dunia usaha di Indonesia menjadi semakin meningkat. para pelaku dunia usaha dalam negeri akan terdegradasi atau tersingkir oleh para pelaku dunia usaha asing apabila tidak mampu mempersiapkan diri sebaik mungkin pada berbagai sektor guna meningkatkan daya saingnya.

Sektor agribisnis merupakan salah satu sektor usaha yang mempunyai peranan penting dalam pembangunan dan perekonomian baik secara nasional maupun daerah. Sektor usaha yang saat ini sedang berkembang adalah tanaman hias. Indonesia masih berpeluang besar untuk mengisi pasar dunia mengingat potensi sumberdaya genetik, sumberdaya alam dan ketersediaan teknologi yang cukup menggembirakan. Perhatian masyarakat Indonesia terhadap tanaman hias tropis semakin meningkat dari tahun ke tahun sejalan dengan perkembangan preferensipasar. Minat masyarakatuntuk menanam tanaman hias secara komersial juga semakin besar. Hal itu menjadikan suatu peluang dan sekaligus tantangan bagi pengembangan industri tanaman hias di Indonesia (Sari, 2008). Menurut Direktorat Jendral Holtikultura (2013) tanaman hias merupakan salah satu sub sektor agribisnis yang mempunyai nilai ekonomi tinggi dan memiliki prospek yang sangat cerah sebagai komoditas unggulan ekspor maupun untuk pemasaran di dalam negeri. Menurut Bank Indonesia (BI) (2008) yang melakukan. penelitian pola pembiayan usaha kecil industri tanaman hias kota Bogor pada tahun 2008 menyebutkan bahwa ada sekitar 15 pengusaha besar, dan 20 pengusaha kecil serta beberapa koperasi yang terdiri dari gabungan antara petani dan pedagang dengan skala usaha yang bervariasi. Jumlah pengusaha tanaman hias yang cukup banyak tersebut akan mengakibatkan persaingan antar pengusaha.

PT. Pesona Daun Mas Asri (PT PDMA) pada tahun 2015 mengalami penurunan penjualan sekitar 10$20 \%$. Penurunan penjualan tersebut diduga karena pertumbuhan pengusaha tanaman hias terus meningkat sehingga para konsumen mulai beralih ke para pesaing perusahaan. Di samping itu, menurut manajemen PT
PDMA mulai masuknya bunga impor dari Vietnam dan Thailand juga memepengaruhi pendapatan mereka. Penurunan penjualan tersebut menjadi masalah bagi perkembangan usaha PT PDMA, dimana modal usaha perusahaan sangat mengandalkan hasil penjualan. Analisis daya saing direkomendasikan untuk mendukung kemampuan PT PDMA dalam rangka menciptakan tingkat pendapatan yang relatif tinggi, sambil tetap mempertahankan kemampuan bersaing dengan menerapkan strategi-strategi bisnis yang tepat. Menurut Porter (1985) Analisis rantai nilai dapat digunakan sebagai pendekatan dalam menyusun strategi, membantu pemahaman mengenai faktorfaktor yang memengaruhi keunggulan kompetitif, dan mengidentifikasi hubungan di antara berbagai aktivitas yang menciptakan nilai.

Tinjaun penelitian terdahulu yang terkait dengan penelitian ini. Ratih et al. (2012) yang melakukan penelitian analisis daya saing berdasarkan aktivitas rantai nilai perusahaan tanaman hias menjelaskan Penekanan strategi peningkatan daya saing industri florikultura adalah konsentrasi melalui integrasi horizontal. Integrasi horizontal dapat dicapai dengan cara menurunkan harga, mengembangkan produk baru, meningkatkan kualitas produk dan jasa atau meningkatkan akses yang lebih luas. Jika dilihat dari luas area dan dibandingkan dengan pasar industri florikultura yang ada di domestik maupun di mancanegara. Menurut Her et al. (2013) Identifikasi tanaman baik secara fisik maupun hortikultura, pemilihan dan penepatan tanaman hias akan menjadi lebih tepat dan sesuai, sesuai dengan kedua karakter tersebut. Pengelolaan tanaman menjadi lebih mudah karena pemilihan tanaman yang tepat, serta fungsi tanaman akan menjadi lebih optimal. Handayati (2013) menjelaskan Seiring dengan kebutuhan tanaman hias dalam negeri yang terus meningkat dan selera konsumen yang cepat berubah, pemulia dalam negeri dalam 5 tahun terakhir telah melepas sekitar 102 varietas unggul baru. Namun, hasil tersebut belum dapat mensubsitusi varietas-varietas impor. Menurut Mujilahwati (2014) masalah yang sering dialami oleh para petani tanaman hias adalah hama penyakit yang menyerang tanaman, sehingga diperlukan konsultan atau badan litbang yang dapat menyelesaikan masalah tersebut. Menurut Sutedi (2011) Bisnis tanaman hias semakin hari semakin berkembang dan diikuti dengan semakin banyaknya permintaan tanaman hias terutama di kota-kota besar. Yayasan Bunga Nusantara memperkirakan di Indonesia terdapat sedikitnya 20.000 petani tanaman hias yang tersebar di berbagai wilayah 
Indonesia. Hal tersebut membawa dampak yang sangat positif bagi petani untuk dapat meningkatkan taraf hidupnya dan juga turut serta dalam hal memperkecil pengangguran yang ada di Indonesia, serta bisa jadi merupakan salah satu sumber devisa negara yang cukup potensial jika tanaman hias tersebut diekspor keluar negeri. Rantai nilai memberikan wahana mengidentifikasi cara untuk menciptakan diferensiasi melalui pengembangan nilai (Wisdaningrum, 2013). Aktivitas rantai nilai dikategorikan menjadi dua jenis, yaitu aktvitas primer (logistic inbound, operasi, logistic out-bound, pemasaran, penjualan, dan jasa) dan aktivitas pendukung (infrastruktur, manajemen sumber daya manusia, pengembangan teknologi dan pengadaan). Aktivitas pendukung ini senantiasa akan menyatukan fungsi-fungsi yang melintasi aktivitas primer yang beraneka ragam serta juga bermanfaat untuk membagi lebih lanjut aktivitas primer spesifik di dalam rantai nilai. Tata kelola dalam suatu rantai nilai mengacu pada struktur hubungan dan mekanisme koordinasi yang terjadi antara para pelaku dalam rantai nilai. Tata kelola merupakan konsep yang luas yang pada dasarnya memastikan bahwa interaksi antara para peserta di dalam rantai nilai telah terorganisir (Rita et al. 2015).

Menurut Friska (2010) keunggulan kompetitif jangka panjang dengan penekanan dan penyempurnaan pada aktivitas rantai nilai dapat dicapai dengan keunggulan biaya atau biaya yang jauh lebih rendah dibandingkan dengan jumlah yang dapat ditandingi oleh para pesaing secara berkesinambungan. Daya saing komoditas dilihat dari 2 indikator, yaitu keunggulan kompetitif dan keunggulan komparatif. Keunggulan kompetitif (competitive advantage) merupakan alatyang digunakan untuk mengukur daya saing suatu aktivitas berdasarkan pada kondisi perekonomian aktual (Nayantakaningtyas dan Daryanto, 2012). Tingkat persaingan yang tinggi menuntut perusahaan untuk menghasilkan produk yang berkualitas tinggi dengan harga murah sehingga perusahaan perlu memberikan perhatian serius terhadap biaya kualitas. Analisis yang tepat terhadap biaya kualitas memungkinkan perusahaan untuk mengetahui sumber-sumber biaya kualitas yang tidak effisien sehingga dapat diambil tindakan yang tepat dan sesuai untuk mengatasinya (Felecia dan Tessa, 2004).

Menurut Adelita et al. (2010) Tingkat persaingan di pasar tanaman hias menjadi sangat ketat. Hampir disetiap perumahan baru, atau jalan masuk menuju perumahan baru dipenuhi oleh pedagang tanaman hias. Ada yang berniaga di pinggir jalan, ada juga berniaga di tempat pembibitan/pembenihan (nursery). Semua berlomba-lomba menjual tanaman ke konsumen. Sebagai ilustrasi harga tanaman hias yang hampir tidak pernah berubah dalam lima tahun terakhir ini mengindikasikan kerasnya persaingan usaha di industri tanaman hias

Tujuan dari penelitian ini adalah Menggambarkan keadaan umum penjualan PT PDMA selama 3 tahun terakhir dan menganalisis rantai nilai tanaman hias di PT PDMA. Menurut Kaplinsky dan Morris (2001) analisis rantai nilai adalah kegiatan lengkap yang diawali dari konsep, fase produksi dan fase pemasaran/pengiriman. Fase pemasaran ke pelanggan bisa melaui pedagang, pengolah dan distributor sehingga perusahaan memiliki keunggulan kompetitif.

\section{METODE PENELITIAN}

Penelitian ini dilakukan di PT. Pesona Daun Mas Asri yang berlokasi di Bogor, Provinsi Jawa Barat. Penelitian menggunakan metode deskriptif dalam bentuk studi kasus. Pendekatan yang digunakan adalah analisis rantai nilai. Jenis data yang dikumpulkan terdiri dari dua jenis, yaitu data primer dan data sekunder. Data primer diperoleh melalui wawancara mendalam dan pengisian kuesioner oleh para aktor rantai nilai untuk memperoleh informasi kondisi rantai nilai di PT. Pesona Daun Mas Asri. Data sekunder diperoleh dari laporan penjualan atau dokumen-dokumen perusahaan dan buku maupun jurnal-jurnal yang memuat informasi yang berguna bagi penelitian ini. Metode pengambilan responden menggunakan teknik snow ball sampling, yaitu satu responden kunci memberikan informasi tentang responden kunci lain dalam satu jalur rantai nilai. Responden dalam penelitain dijabarkan pada Tabel 1.

Tabel 1. Responden pada penelitian

\begin{tabular}{lcl}
\hline Kategori/Jabatan & Jumlah & \multicolumn{1}{c}{ Jenis Data } \\
\hline PT PDMA & 2 & $\begin{array}{l}\text { Rantai Nilai, Kondisi } \\
\text { umum penjualan }\end{array}$ \\
Pesaing & 1 & Rantai nilai \\
Petani & 1 & Rantai nilai \\
Trader & 1 & Rantai Nilai \\
Florist & 1 & Rantai Nilai \\
\hline
\end{tabular}


Data penjualan perusahaan selama tiga tahun terakhir digunakan untuk mendapatkan infornasi produk ungggulan perusahaan serta trend penjualan, sehingga didapatkan gambaran umum kekuatan pasar PT PDMA. Analisis rantai nilai digunakan untuk mengindentifikasi masalah yang dihadapi perusahaan serta mendapatkan informasi kekuatan internal perusahaan. (Kaplinsky and Morris, 2000) tahapan-tahapan dalam melakukan analisis rantai nilai adalah sebagai berikut:

1. Identifikasi proses rantai nilai di PT PDMA sebagai Titik Awal Analisis (The Point of Entry), Titik awal ini kemudian dapat dirunut ke pelaku yang ada di belakang (hulu) dan atau ke depan (hilir).

2. Pemetaan Rantai Nilai, memetakan aliran produk dan analisis nilai margin dengan membandingkan harga jual disetiap aktor.

3. Faktor kunci keberhasilan Pasar tujuan (Critical Success Factor), Orientasi keberhasilan suatu produk bukan ditentukan oleh kekuatan perusahaan untuk memasok sejumlah produknya. Namun, ditentukan oleh kemampuan perusahaan (jaringan, teknologi, produksi dan sebagainya) untuk memenuhi kebutuhan pasar baik dalam kuantitas maupun kualitas yang sesuai.

4. Melakukan benchmarking dengan kompetitor, beberapa hal yang dapat dibandingkan adalah dayasaing harga dan sistem pemasaran.

5. Mengkoordinasi rantai nilai dengan jejaring yang terkait Analisis lembaga terkait ditentukan setelah pelaku dan peta rantai nilai diketahui maka perlu diidentifikasi lembaga terkait mana saja yang dapat dilibatkan. Setelah didapatkan hasil analisis rantai nilai, maka akan diketahui permasalah yang dihadapi perusahaan serta kekuatan internal perusahaan dalam menghadapi persaingan.

Penelitian ini diawali dengan mendeskripsikan keadaan penjualan PT PDMA selama tiga tahun terakhir, hal ini dilakukan untuk mendapatkan gambaran jenis-jenis tanaman hias yang memengaruhi penjualan PT PDMA dan untuk mengetahui tren penjualan PT PDMA. Analisis rantai nilai dilakukan untuk mendapatkan faktor-faktor internal yang memengaruhi dayasaing PT PDMA dalam menjalankan bisnisnya. Kerangka pemikiran penelitian pada Gambar 1 .

\section{HASIL}

\section{Deskripsi Penjualan PT PDMA}

PT Pesona Daun Mas Asri dalam mencapai visi dan misinya terus berupaya meningkatkan penjualan untuk memperoleh keuntungan yang maksimal. Kegiatan usaha yang dilakukan selain sebagai produsen daun potong dan bunga potong, PT PDMA juga beperan sebagai trader. Perkembangan tren jenis tanaman hias yang terus berubah-ubah sangat memengaruhi preferensi konsumen, untuk mengikuti perubahan tren tersebut perusahaan menjalin kerja sama dengan perusahaan lain/petani. Jenis-jenis tanaman hias yang dijual oleh PT PDMA sekitar 43 jenis, baik yang dikembangkan/ dibudidayakan sendiri oleh PT PDMA maupun jenis yang disupply oleh petani/mitra.

Total luas kebun yang dimiliki oleh PT PDMA adalah 3 Ha, dengan luas tersebut PT PDMA tidak bisa menanam semua jenis tanaman dalam waktu yang bersamaan. Awalnya jenis-jenis tanaman yang dibudidayakan oleh PT PDMA didominasi oleh daun potong, namun sering berjalannya waktu PT PDMA mulai mengembangkan untuk jenis bunga potong. Jenis-jenis tanaman yang menjadi produk unggulan di PT PDMA diantaranya adalah Philodendron marble, philodendron selloum dan Asparagus myriocladus untuk jenis daun potong sedangkan Gerbera, dan Celosia untuk jenis bunga potong.

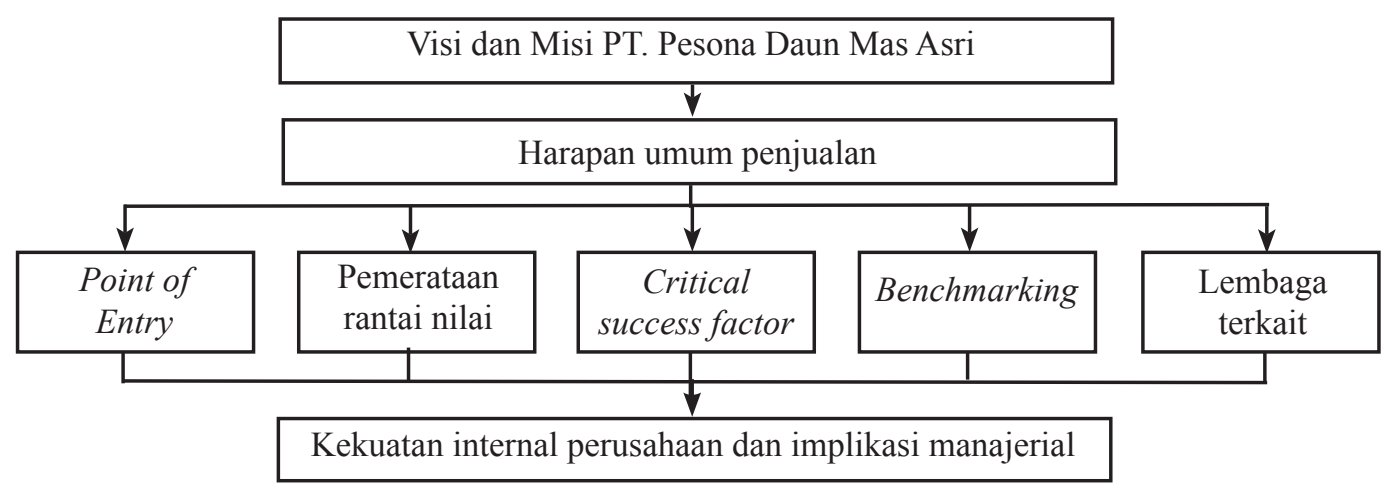

Gambar 1. Kerangka pemikiran penelitian 


\section{Philodendron marble dan philodendron selloum}

Philodendron berasal dari bahasa Yunani, philo artinya cinta dan dendron artinya daun tanaman ini termasuk keluarga Araceae, seperti halnya Aglonema, Anthurium, dan Caladium.Philodendron juga mempunyai daya tarik pada bentuk dan warna daunnya, diantaranya: seperti hati, lonjong berujung lancip, menjari, warna daun bermacam-macam yang mampu menampilkan pesona keindahan (Lingga, 2007). Perbedaan dari kedua jenis tersebut adalah dari bentuk daun.

\section{Asparagus myriocladus}

Tanaman ini lebih populer dengan sebutan asparagus bintang. Batangnya berkayu dan bercabang banyak. Tumbuhnya tegak. Daun-daun jarumnya yang kecilkecil dan terangkai menyerupai bintang itulah yang membuatnya dijuluki asparagus bintang. Waktu masih muda daunnya berwarna kekuningan dan kemudian berangsur-angsur berubah menjadi hijau. Budi daya yang dilakukan oleh PT. PDMA yaitu dengan cara di stek. Tanaman ini sangat berguna untuk hiasan didalam ruangan maupun dijadikan sebagai rangkaian bunga.

\section{Gerbera}

Tumbuhan ini dapat ditanam mulai dari dataran rendah sampai dataran tinggi (pegunungan). Daerah yang paling baik untuk pengembangan tanaman ini adalah dataran tinggi yang beriklim sejuk. Penanaman gerbera di dataran rendah yang suhu udaranya panas sering kali menyebabkan perubahan warna mahkota bunga menjadi lebih pucat dari warna aslinya. Menurut Nurmalinda dan Yani (2009) Gerbera merupakan salah satu jenis bunga yang menarik untuk dirangkai. Warna bunganya yang beragam dapat dirangkai sebagai rangkaian utama dan dapat juga dipadukan dengan bunga-bunga lain, seperti anggrek, snap dragon, krisan, dan sebagainya.

\section{Celosia cristata}

Tanaman ini lebih dikenal dengan nama bunga jengger ayam. Masa berbunga tanaman ini bisa beberapa kali dalam satu bulan. Tanaman ini mempunyai bunga dengan bentuk seperti jengger ayam. Bunganya berwarna merah, ungu, oranye, dan kuning yang tahan hingga beberapa minggu.

Penjualan lima produk unggulan tersebut menghasilkan 50-55\% dari total omset yang diterima oleh PT PDMA. Menurut manajemen PT PDMA mulai dari bulan Oktober sampai dengan bulan Februari merupakan high season, dimana permintaan terhadap daun potong dan bunga potong meningkat (Gambar 2). Perencanaan budi daya tanaman yang akan dijual pada bulan tersebut telah dilakukan pada awal tahun dengan pertimbangan tren daun potong maupun bunga potong.

Data penjualan keseluruhan jenis tanaman hias PT PDMAselamatiga tahun terakhirmenunjukkanfluktuasi yang idientik dari tahun 2013 hingga 2016. Grafik penjualan pad Gambar 3 menunjukkan bahwa pada tahun 2014-2015 PT PDMA mengalami peningkatan penjualan, hal tersebut disebabkan oleh perusahaan yang awalnya lebih banyak membudidayakan daun potong mulai mengembangkan jenis bunga potong.

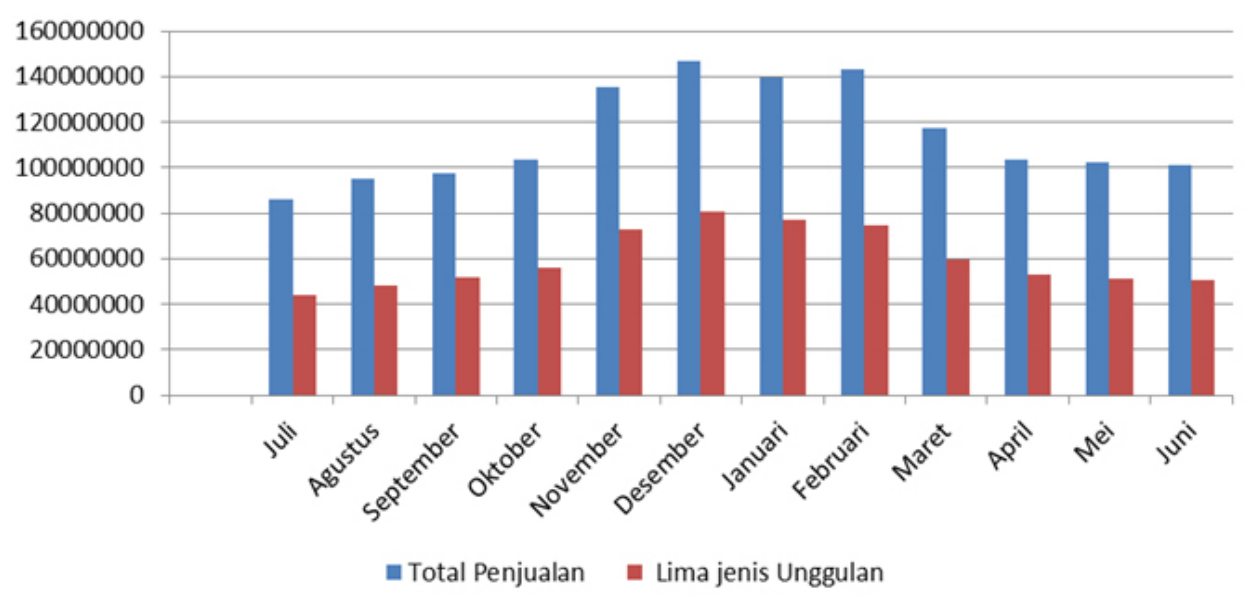

Gambar 2. Perbandingan penjualan produk unggulan 
Data penjualan PT PDMA selama tiga tahun terakhir tersebut dapat digunakan untuk peramalan penjualan pada masa yang akan datang dengan menggunakan analisis tren senderhana. Data penjualan tersebut dianalisis sehingga didapatkan rumus peramalan penjualan sebagai berikut:

$$
\hat{\mathrm{Y}}=126,369-0,154746 . \mathrm{t}
$$

Keterangan: $\hat{Y}$ (penjualan yang diprediksi); $t$ (waktu)

Tanda negatif pada rumus menunjukkan bahwa trend penjualan tanaman hias di PT PDMA sedang mengalami penurunan. Tingkat akurasi model tersebut dapat dijelaskan oleh nilai MAPE, MAD, MSD berturut-turut sebagai berikut 13,56; 16,20; dan 360,27. Menurut Supranto (2003) peramalan tidak memberikan jawaban pasti tentang apa yang akan terjadi, melainkan berusaha mencari pendekatan tentang apa yang akan terjadi sehingga dapat memberikan kontribusi dalam menentukan keputusan yang terbaik. Ramalan penjualan merupakan suatu faktoryang harus diperhatikan didalam perencanaan perusahaan (business planning). Halhal lainnya seperti skedul produksi, pembelian bahan mentah, perencanaan tenaga kerja, biaya advertensi dan pengeluaran-pengeluaran lainnya untuk usaha penjualan serta penanaman modal sangat tergantung pada hasil ramalan penjualan.

\section{Analisis Rantai Nilai PT. Pesona Daun Mas Asri}

Analisis rantai nilai digunakan sebagai pendekatan posisi perusahaan pada rantai nilai produk untuk meningkatkan keunggulan kompetitif/ dayasaing di PT PDMA. Langkah awal untuk melakukan analisis rantai nilai yaitu indentifikasi masalah dan pelaku sebagai titik awal analisis (entry point). Secara garis besar aktivitas rantai nilai didalam PT PDMA untuk menghasilkan produk melalui beberapa tahap, yaitu pengadaan input, proses produksi, dan pemasaran (Gambar 4).

Aktivitas rantai nilai untuk empat produk unggulan di PT. PDMA berbeda antara produk daun potong dengan bunga potong. Perbedaannya terletak pada pengadaan input untuk daun potong tidak berasal dari bibit, melainkan dari hasil stek terhadap tanaman indukan yang ada di kebun sehingga PT. PDMA dapat menekan biaya pengadaan input untuk memproduksi jenis daun potong.
Proses produksi di PT. PDMA dimulai dari kegiatan penanaman, perawatan hingga kegiatan panen. Penanaman tanaman hias dilakukan di kebun dengan luasan sekitar 3 ha, area kebun tersebut dibagi menjadi beberapa bedengan yang kemudian ditanami berbagai jenis tanaman hias. Media tanam yang digunakan adalah tanah yang dicampur dengan sekam dan pupuk, pencampuran tersebut dilakukan untuk menjaga unsur hara dan $\mathrm{pH}$ tanah. Permasalahan utama yang dihadapi oleh PT. PDMA pada kegiatan produksi adalah ketidak tepatan waktu tanaman siap panen dengan permintaan pengiriman oleh konsumen, kemudian dalam beberapa bulan terakhir sering terjadi gagal panen, menurut keterangan manajemen PT PDMA, masalah tersebut terjadi kerena perubahan iklim mikro di sekitar lokasi kebun. Iklim mikro yang dimaksud adalah peningkatan suhu akibat dari pembukaan lahan untuk pembangunan jalan tol BOCIMI. Dampak peningkatan suhu terhadap tanaman menurut Las (2007) adalah terjadinya peningkatan transpirasi yang menurunkan produktivitas, peningkatan konsumsi air, percepatan pematangan buah/biji yang menurunkan mutu hasil, dan perkembangan beberapa organisme pengganggu tanaman.

Kegiatan pemasaran yang dilakukan di PT PDMA adalah menjual produknya melalui pemasaran langsung atau personal selling. Perusahaan mendatangi langsung konsumen dengan alat promosi berupa contoh tanaman dan poster tanaman yang diproduksi. PT PDMA saat ini belum menggunakan media online sebagai sarana marketing. Penjualan tanaman hias selama ini lebih mengandalkan kerja sama dengan beberapa florist dan trader/distributor untuk memasarkan produk perusahaan. permasalah yang dihadapi PT PDMA untuk pemasaran adalah tidak adanya penambahan jumlah pelanggan/konsumen yang signifikan, hal ini disebabkan oleh bagian marketing dari PT PDMA kurang aktif dan kurang memanfaatkan sarana marketing yang ada.

\section{Pemetaan Rantai Nilai}

Pemetaan rantai nilai merupakan suatu model yang digunakan untuk mengetahui pola, peranan, dan aktivitas yang dilakukan oleh setiap aktor yang terdapat dalam rantai nilai tanaman hias. Berbagai aktivitas yang terdapat pada satu rantai nilai bertujuan untuk menciptakan dan meningkatkan nilai tambah serta keunggulan kompetitif bagi perusahaan atau pelaku bisnis. 


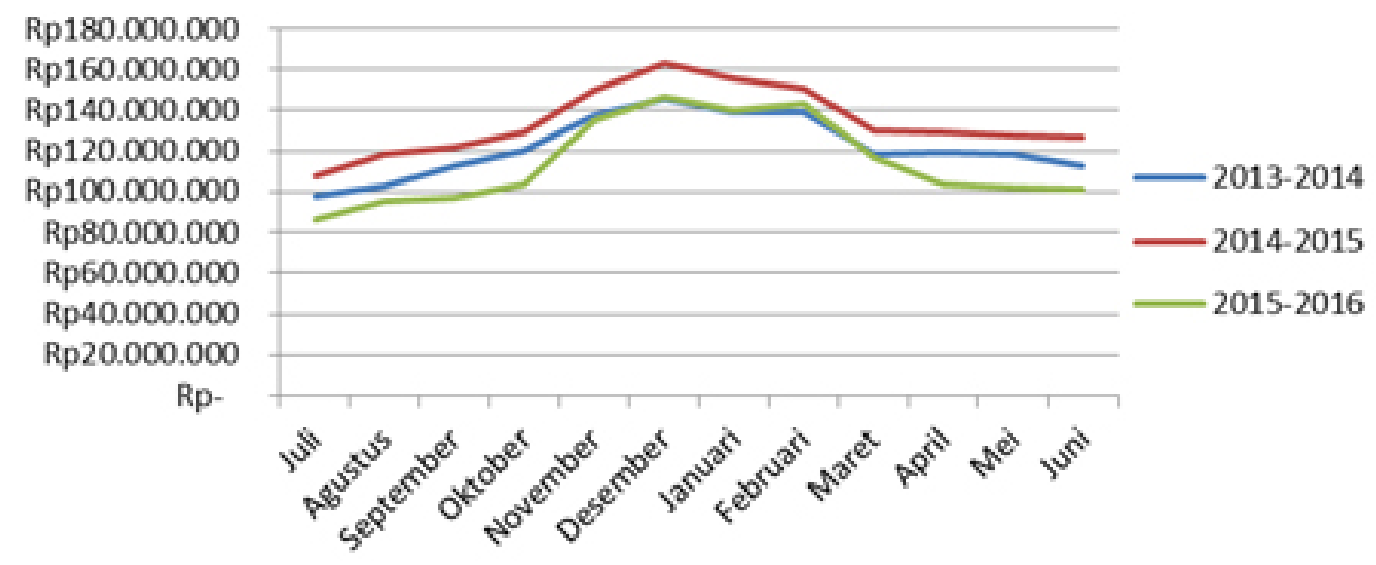

Gambar 3. Perbandingan penjualan

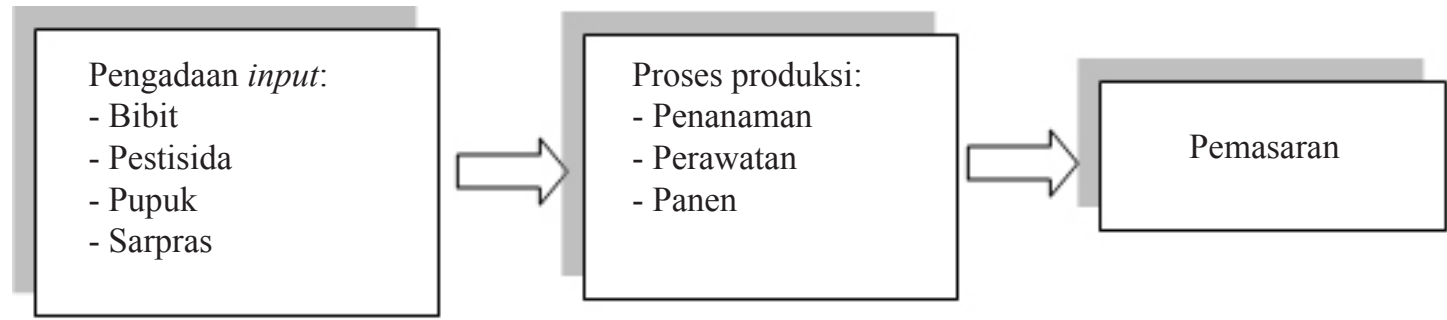

Gambar 4. Alur rantai nilai di PT PDMA

\section{Identifikasi Aktor}

Hasil wawancara dan observasi yang dilakukan terhadap rantai nilai lima jenis unggulan didapatkan informasi bahwa selain sebagai produsen PT. PDMA juga berperan sebagai trader. Dua peran yang dijalankan oleh perusahaan tersebut melibatkan 4 aktor lainnya dari sepanjang rantai nilainya. Aktor-aktor tersebut diantaranya adalah sebagai berikut:

\section{Supplier bibit}

PT PDMA bekerja sama dengan supplier bibit hanya untuk produk bunga potong. Kerja sama antara PT PDMA dengan supplier adalah kerja sama tidak terikat, dimana untuk kedua jenis tanaman bunga yang menjadi produk unggulan PT PDMA bisa mendapatkan dari berbagai supplier dengan pertimbangan harga dan kualitas. Menurut manajemen PT PDMA saat ini perusahaan sedang berupaya untuk menghasilkan bibit sendiri agar beban penggadaan bibit dapat di minimalisir.

\section{Petani Mitra}

Kerja sama anatara PT PDMA dengan petani mitra adalah untuk memenuhi kekurangan hasil produksi. Kerja sama ini tidak bersifat mengikat kedua belah pihak. Para petani mitra berasal dari daerah sekitaran Bogor, Sukabumi dan Cianjur. Dipilihnya para petani didaerah tersebut diakrenakan lokasinya yang berdekatan dengan PT PDMA sehingga biaya pengiriman tidak terlalu mahal. Jenis-jenis tanaman hias yang berasal dari para petani mitra tersebut akan disortasi terlebih dahulu oleh PT PDMA, hal ini dilakukan untuk menjaga kualitas dan kepercayaan konsumen. Harga yang didapatkan oleh PT PDMA dari para petani lebih murah dari harga jualnya, dimana margin yang didapatkan PT PDMA sebesar $15-20 \%$ untuk jenis daun potong dan $20-25 \%$ untuk jenis bunga potong. Risiko yang dihadapi oleh PT PDMA yaitu jika terjadi kerusakan tanaman hias selama waktu pengiriman atau tidak sesuainya kualitas yang diterima dengan yang dipesan menjadi Risiko dan tanggung jawab PT. PDMA. Untuk mengatasi hal tersebut PT. PDMA melakukan penjemputan pesanan/ produk yang dibeli, agar dapat dikontrol kesesuain pesanan dan proses pengiriman. 
Hasil wawancara dengan petani didapatkan informasi Jenis tanaman yang dibudidayakan adalah Philodendron Selloum, Gerbera dan jenis lainnya. Usaha budidaya tanaman hias telah dijalani selama kurang lebih lima tahun. Pemilihan jenis tanaman yang dibudidayakan berasal dari informasi maupun saran dari para pembeli. Harga jual daun potong dan bunga potong ditentukan berdasarkan harga jual sebelumnya, informasi dari pembeli/penawar dan waktu panen.

\section{Florist/Decorator}

Florist adalah istilah umum yang digunakan untuk menggambarkan perdagangan bunga profesional. Kegiatan usahanya meliputi perawatan bunga dan penanganan, desain bunga atau merangkai bunga dan merchandising. Jenis usaha ini biasanya digabungkan dengan usaha dekorasi untuk acara pernikahan maupun acara besar lainnya. Hubungan kerja sama antara PT. PDMA dengan Florist biasanya menggunakan sistem konsinyasi, dimana PT. PDMA harus menyediakan daun potong dan bunga potong setiap minggu, pembayaran oleh florist dilakukan jika produk yang di pasok laku terjual, untuk produk yang tidak laku terjual akan dikembalikan ke PT. PDMA.

XYZ Florist merupakan salah satu perusahaan yang menjalin kerja sama dengan PT. PDMA. Usaha yang dijalankan yaitu menjual bouqet bunga, karangan bunga serta dekorasi. Perjanjian kerja sama yang dilakukan dengan tujuan untuk menjaga pasokan tanaman hias, menurut manajer XYZ Florist pada bulan OktoberFebruari merupakan high season penjualan. Jenis daun potong Philodendron marble, selloum dan asparagus bintang biasanya digunakan untuk pembuatan karangan bunga dan bouqet bunga, begitu juga untuk dua jenis bunga potong gerebera dan celosia, khusus untuk gerbera bisa dijual satuan. Menurut XYZ Florist keunggulan daun potong dan bunga potong dari PT. PDMA, yaitu kualitas bagus yang dilihat dari ukuran dan warnanya.

\section{Trader}

Perkembangan usaha trader tanaman hias saat ini semakin berkembang, para pelaku usaha ini biasanya menjadikan perdagangan tanaman hias sebagai usaha sampingan. Kelebihan usaha trader ini adalah tidak adanya risiko gagal panen dan para pelaku usaha tidak memerlukan lahan atau media tanam. Konsumen yang menjadi target dari para trader biasaanya adalah hotel- hotel yang memiliki dekorator sendiri. Kerja sama yang terjadi antara PT PDMA dengan para trader tidak memiliki ikatan. Menurut manajemen PT PDMA para trader tersebut merupakan salah satu pesaing yang jumlahnya terus bertambah.

Hasil wawancara dengan trader didapatkan infromasi bahwa, bisnis ini berawal dari permintaan dari temannya yang bekerja disalah satu hotel berbintang di Jakarta untuk mencarikan bunga potong jenis Gerbera. Atas dasar itu trader tersebut mendirikan CV. Rekacita Intan Semesta sebagai perusahaan resmi supplier tanaman hias untuk hotel tersebut. Margin yang didapatkan oleh Bapak Endang yaitu sebesar 15-20\% dari harga beli.

Berdasarkan pada Gambar 5, maka dapat di peroleh informasi aktor-aktor rantai nilai tanaman hias diatas dapat menghasilkan 9 pola aliran komoditas dan aliran nilai, yaitu sebagai berikut:

1. Supplier Bibit $\rightarrow$ PT. PDMA $\rightarrow$ Florist $\rightarrow$ End User

2. Supplier Bibit $\rightarrow$ PT. PDMA $\rightarrow$ End User

3. Supplier Bibit $\rightarrow$ PT. PDMA $\rightarrow$ Trader $\rightarrow$ End User

4. PT. PDMA $\rightarrow$ End User

5. PT. PDMA $\rightarrow$ Florist $\rightarrow$ End User

6. PT. PDMA $\rightarrow$ Trader $\rightarrow$ End User

7. Petani Mitra $\rightarrow$ PT. PDMA $\rightarrow$ Florist $\rightarrow$ End User

8. Petani Mitra $\rightarrow$ PT. PDMA $\rightarrow$ End User

9. Petani Mitra $\rightarrow$ PT. PDMA $\rightarrow$ Trader $\rightarrow$ End User

Pola aliran 1, 2 dan 3 adalah pola aliran untuk jenis bunga potong, PT PDMA mendapatkan supply bibit bunga potong dengan harga Rp3000/benih untuk jenis gerbera, satu benih gerbera akan menghasilkan satu rumpun dengan produktivitas rata-rata sepuluh tangkai bunga per rumpum, sedangkan untuk jenis celosia PT PDMA mendapatkan harga Rp1200/benih dengan ratarata menghasilkan dua sampai tiga tangkai bunga, untuk menghasilkan sepuluh tangkai bunga diperlukan empat benih tanaman celosia. Menurut keterangan manajemen PT PDMA biaya produksi untuk sepuluh tangkai bunga gerbera dan celosia adalah sebesar Rp4.200 sedangkan harga jual gerbera Rp16.000/ikat dan celosia Rp20.000/ ikat. Pola aliran 1 PT PDMA menjual bunga gerbera dan celosia kepada florist/decorator, kedua bunga tersebut nantinya akan dikombinasikan dengan jenis bunga yang lain untuk pembuatan bouquet bunga maupun karangan bunga, adapun satu bouquet bunga dijual dengan harga sebesar Rp500000 dan karangan bunga sebesar Rp800000. Pola aliran 2 PT PDMA 
menjual langsung kepada end user (Hotel berbintang). Pola aliran 3 PT PDMA menjual bunga potong kepada trader yang nantinya akan dijual kembali kepada konsumen mereka, harga bunga potong pada tingkat trader mengalami peningkatan, trader menjual gerbera dengan harga Rp19.200 dan celosia Rp24.000.

Pola aliran 4, 5 dan 6 merupakan aliran daun potong, pada pembahasan sebelumnya telah disampaikan bahwa PT PDMA dalam memproduksi daun potong menggunakan teknik stek untuk memperbanyak tanamannya sehingga tidak memerlukan supply bibit. Rata-rata biaya produksi untuk jenis daun potong menurut keterangan manajemen PT PDMA adalah sebesar Rp6.600/sepuluh daun. Penjualan terbanyak PT PDMA untuk jenis daun potong adalah untuk ukuran M dan L dengan harga rata-rata sebesar Rp10.250/ sepuluh daun jenis Marble, Rp10.750/sepuluh daun jenis asparagus dan Rp6.000/lima daun jenis selloum. Pola aliran 4 PT PDMA menjual langsung kepada end user sehingga tidak terjadi peningkatan harga. Pola aliran 5
PT PDMA menjual kepada florist dimana daun-daun tersebut akan digunakan untuk pembuatan bouquet bunga dan karangan bunga. Pola aliran 6 PT PDMA menjual kepada trader, pada tingkat trader ini terjadi peningkatan harga jual daun-daun tersebut menjadi Rp12.300/sepuluh daun jenis Marble, Rp12.900/ sepuluh daun jenis asparagus dan Rp7.200/lima daun jenis selloum.

Pola aliran 7, 8, dan 9 terjadi karena PT PDMA mendapatkan supply bunga potong dan daun potong dari petani mitra. Harga jual bunga potong dan daung potong pada masing-masing aktor dapat dilihat pada Tabel 2. Margin penjualan yang didapatkan oleh PT PDMA dapat dibagi menjadi dua, pertama adalah margin yang didapatkan dari hasil produksi dan yang kedua adalah margin yang didapatkan dari penjualan yang di-supply oleh petani mitra. Perhitungan margin yang didapatkan dari hasil produksi dapat dilihat pada Tabel 3.

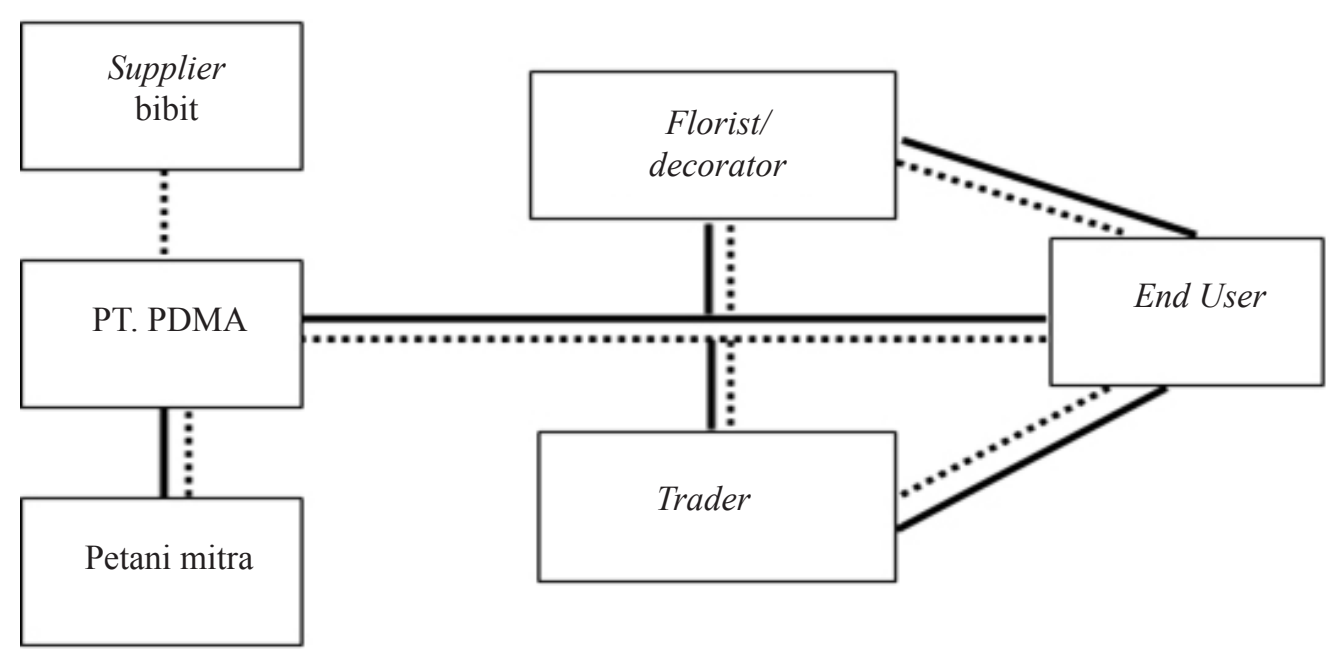

Gambar 5. Rantai nilai 4 Produk unggulan ( ----- Aliran bunga potong; —— Aliran daun potong)

Tabel 2. Harga lima jenis tanaman hias pada setiap aktor (Rupiah per ikat)

\begin{tabular}{lcccl}
\hline \multirow{2}{*}{ Jenis } & \multicolumn{4}{c}{ Harga pada masing-masing aktor } \\
\cline { 2 - 5 } & Petani Mitra & PT. PDMA & Trader & \multicolumn{1}{c}{ Florist } \\
\hline Marble & 8.200 & 10.250 & 12.300 & *Harga 1 bucket bunga (gambar 12) : \\
Aparagus & 8.600 & 10.750 & 12.900 & 500000 \\
Selloum & 4.800 & 6.000 & 7.200 & *Harga rangkaian bunga 800000 \\
Gerbera & 12.000 & 16.000 & 19.200 & \\
Celosia & 15.000 & 20.000 & 24.000 & \\
\hline
\end{tabular}


Biaya produksi untuk jenis bunga potong lebih besar dari daun ptong disebabkan biaya perawatan seperti pemupukan dan penyemprotan pestisida lebih sering dilakukan. Perbedaan biaya produksi tersbut menyebabkan perbedaan Margin yang didapatkan pada masing-masing jenis. Margin penjualan terbesar diperoleh dari penjualan bunga celosia dengan persentase sebesar $47 \%$. Margin yang didapatkan oleh PT PDMA jika mendapatkan supply atau membeli bunga potong dan daun potong dari petani mitra dapat dilihat pada Tabel 4.

Margin yang didapatkan oleh PT PDMA lebih kecil jika dibandingkan dengan hasil produksi perusahaan. margin terbesar didapatkan dari penjualan bunga potong jenis celosia. Menurut manajemen PT PDMA saat ini perusahaan lebih memilih mendapatkan supply dari petani walaupun margin yang didapatkan lebih kecil namun perusahaan dapat menghindari kegagalan produksi. Marjin pemasaran menunjukan selisih harga dari dua tingkat rantai pemasaran (Daly dan George, 2002).

\section{Faktor Kunci Keberhasilan Pasar Tujuan}

Hasil wawancara, didapatkan hasil bahwa faktor kunci keberhasilan PT PDMA dalam menjual tanaman hias, khususnya untuk kelima produk unggulan adalah kualitas dan kesegaran dari tanaman hias. Kualitas daun potong yang bagus dapat lihat warna daun. Daun potong yang berkualitas bagus yaitu daun yang berwarna hijau mengkilap dan tidak adanya bercak-bercak pada daun. Kualitas bunga potong untuk jenis Gerbera dan Celosia agar dapat diterima di pasaran dapat dilihat pada Tabel 5.

Segmen pasar yang dituju oleh PT PDMA jika dilihat dari jenis tanaman hias yang dihasilkan adalah segmen pasar bucket bunga, rangkain bunga dan dekorasi ruangan untuk acara pernikahan, perayaan ulang tahun, dan dekorasi hotel berbintang.

Tabel 3. Analisis margin penjualan lima jenis unggulan berdasarkan hasil produksi (Rupiah per ikat)

\begin{tabular}{lcccc}
\hline Jenis & Bibit & Biaya Produksi & Harga Jual & Margin \\
\hline Celosia & 4.800 & 5.900 & 20.000 & 9.300 \\
Gerbera & 3.000 & 5.900 & 16.000 & 7.100 \\
Marble & & 5.300 & 10.250 & 4.950 \\
Asparagus & & 5.300 & 10.750 & 5.450 \\
Selloum* & & 5.300 & 12.000 & 6.700 \\
\hline
\end{tabular}

*Harga jual 2 ikat

Tabel 4. Analisis margin penjualan lima jenis unggulan berdasarkan hasil pembelian dari petani mitra (Rp per ikat)

\begin{tabular}{lcccc}
\hline Jenis & Harga beli & Harga jual & Margin & Margin \\
\hline Celosia & 15.000 & 20.000 & 5.000 & 9.300 \\
Gerbera & 12.000 & 16.000 & 4.000 & 7.100 \\
Marble & 8.200 & 10.250 & 2.050 & 4.950 \\
Asparagus & 8.600 & 10.750 & 2.150 & 5.450 \\
Selloum* & 9.600 & 12.000 & 2.400 & 6.700 \\
\hline
\end{tabular}

*Harga jual 2 ikat

Tabel 5. Standar kualitas bunga potong dipasaran

\begin{tabular}{ll}
\hline \multicolumn{1}{c}{ Jenis } & \multicolumn{1}{c}{ Standar kualitas } \\
\hline Gerbera & panjang tangkai $25-60 \mathrm{~cm}$, Diameter bunga $7,5-12 \mathrm{~cm}$ \\
Celosia & panjang tangkai $25-60 \mathrm{~cm}$, Panjang bunga $5-7 \mathrm{~cm}$ \\
\hline
\end{tabular}




\section{Perbandingan dengan Pesaing (Benchmarking)}

Pesaing PT PDMA dalam produksi daun potong adalah para petani, menurut manajemen PT PDMA para petani tersebut memiliki lahan yang lebih kecil sehingga produktivitasnya reatif kecil dari PT PDMA namun jumlah mereka yang cukup banyak menjadikan mereka sebagai pesaing utama dalam penjualan daun potong. Pesaing untuk jenis bunga potong adalah PT KC. Yang berlokasi di Jawa Barat. Perussahaan ini dipilih sebagai pembanding karena menurut manajemen PT PDMA perkembangan bisnis tanaman hias perusahaan tersebut meningkat. Di samping itu, PT KC juga memproduksi bunga jenis celosia dan gerbera yang menjadi produk unggulan dari PT PDMA. Perbandingan harga kedua bunga potong tersebut dapat dilihat pada Tabel 6 .

Tabel 6. Perbandingan harga dua jenis bunga potong

\begin{tabular}{lcc}
\hline \multirow{2}{*}{ Perusahaan } & \multicolumn{2}{c}{ Perbandingan harga produk } \\
\cline { 2 - 3 } & Celosia & Gerbera \\
\hline PT. PDMA & 20.000 & 16.000 \\
PT. KC & 32.400 & 16.800 \\
\hline
\end{tabular}

Perbandingan luas lahan dan sarana produksi kedua perusahaan dapat menggambarkan kemampuan perusahaan dalam hal kuantitas dari bunga potong yang dihasilkan, Luas lahan/kebun yang dimiliki oleh PT. KC adalah sekitar 6 ha, dua kali lebih besar dari PT. PDMA, dengan luas lahan tersebut PT. KC dapat mengembangkan banyak jenis maupun memperluas areal penanaman jenis-jenis unggulan. Sarana/tempat penanam bunga potong kedua perusahaan memiliki perbedaan, dimana PT. KC dalam mengembangkan tanaman hias membangunan greenhouse yang digunakan untuk memodifikasi iklim mikro pada tanaman, sedangkan di PT. PDMA tidak memiliki greenhouse yang menyebabkan perusahaan mengalami gagal panen yang disebabkan oleh perubahan dari iklim mikro. Tujuan penggunaan greenhouse adalah agar tercipta kondisi lingkungan yang mendukung pertumbuhan tanaman. Kondisi lingkungan yang dapat di hindari oleh greenhouse dalam budi daya tanaman, yaitu sebagai berikut:

1. Fluktuasi perubahan suhu dan kelembaban udara

2. Kekurangan air pada musim kemarau dan kelebihan air pada musim penghujan.

3. Hama dan binatang pengganggu serta penyakit tanaman seperti jamur dan bakteri.

4. Tiupan angin kencang yang dapat merobohkan tanaman dan merusak daun.
Sistem pemasaran yang dilakukan oleh PT KC lebih unggul dari PT PDMA, disamping melakukan personal selling PT KC juga memanfaatkan media online seperti web, instagram dan dibukannya kantor pemasaran dijakarta menjadikan PT KC lebih mudah dalam mengakses pasar. PT KC mulai mengembangkan bisnis dalam bentuk agrowisata untuk meningkatkan pendapatannya. Menurut (Mangold dan Faulds, 2009) sosial media memiliki pengaruh besar bagi pemasar. Promosi pada media sosial terkait dengan promosi tradisional seperti sales promotion, periklanan, public relations, personalselling, dandirectmarketing. Melihat penyebaran informasi yang bebas dan luas pemasar harus memiliki strategi dalam mengkomunikasikan pesan yang akan disampaikan kepada khalayak sasaran di sosial media.

\section{Peran Kelembagaan Terkait}

PT PDMA merupakan member dari Asosiasi Bunga Indonesia (ASBINDO) yang merupakan organisasi yang bertujuan memperkuat bisnis florikultura nasional pada umumnya dan perusahaan anggota pada khususnya melalui kegiatan pelatihan, layanan bisnis, dan promosi produk florikultura. Salah satu kegiatan rutin yang dilakukan oleh ASBINDO adalah pameran produk-produk florikultura serta sharing tentang trend tanaman hias. Manfaat yang dirasakan oleh PT PDMA adalah dengan ikut keanggotaan tersebut perusahaan dapat mengikuti perkembangan atau trend tanaman hias.

\section{Implikasi Manajerial}

Hasil analisis rantai nilai yang telah dilakukan maka didapatkan kekuatan internal perusahaan adalah pada harga produk yang lebih murah jika dibandingkan dengan pesaing dan PT PDMA selalu mengikuti trend tanaman hias yang berkembang di saat ini. Langkah yang harus dilakukan PT PDMA untuk meningkatkan penjualan adalah dengan memaksimalkan bagian marketing perusahaan, penjualan dilakukan tidak hanya mengandalkan personal selling, tetapi PT PDMA dapat memanfaatkan sarana/media online, kemudian PT PDMA harus memikirkan perluasan cakupan bisnis dengan mengembangkan usaha dalam bentuk agrowisata. 


\section{KESIMPULAN DAN SARAN}

\section{Kesimpulan}

Penjualan tanaman hias oleh PT PDMA dipengaruhi oleh lima produk unggulan, yaitu Phillodendron marble, phillodendron selloum, Asparagus bintang, gerbera dan celosia. Secara keseluruhan trend penjualan tanaman hias PT PDMA mengalami penurunan yang disebabkan oleh faktor eksternal maupun internal perusahaan.

Analisis rantai nilai tanaman hias di PT PDMA dapat disimpulkan bahwa masalah utama yang dihadapi oleh atau faktor internal yang menyebabkan penurunan penjualan PT PDMA adalah pada proses produksi dan pemasaran. Kekuatan PT PDMA dalam menghadapi persaingan adalah pada harga yang murah jika dibandingkan dengan pesaing serta penjualan jenis tanaman hias selalu mengikuti yang berkembang. Margin yang diperoleh PT PDMA dari hasil produksi adalah $40 \%$ untuk jenis daun potong dan $55 \%$ dari jenis bunga potong. Margin yang didapatkan dari pemasok, yaitu petani mitra adalah $20 \%$ untuk daun potong dan $25 \%$ untuk bunga potong.

\section{Saran}

PT. PDMA harus mampu mengatasi permasalahan internal mulai dari proses produksi, yaitu dengan menggunakan teknologi untuk meminimalisir dampak dari perubahan iklim. Metode pemasaran perusahaan seharusnya tidak mengandalkan personal selling saja. Namun, juga memanfaatkan sarana lain seperti media online.

\section{DAFTAR PUSTAKA}

Adelita, Musa H, Darwin K. 2010. Kelayakan dan strategi pengembangan usaha pembudidayaan tanaman hias di kompleks perumahan Bekasi (kasus usaha tanaman hias adenium pada lahan terbatas). MANAJEMEN IKM: Jurnal Manajemen Pengembangan Industri Kecil Menengah 5(1):32-41.

[BI] Bank Indonesia. 2008. Pola Pembiayan Usaha Kecil Industri Tanaman Hias. Jakarta: Bank Indonesia.

Daly A, George F . 2002. Anti-poverty programs in Indonesia. Journal of Indonesian Economic Studies 38(3): 309-330. https://doi. org/10.1080/00074910215535.

Direktorat Jendral Holtikultura Kementrian Pertanian. 2013. Pedoman Teknis peningkatan produksi, produktivitas dan mutu produk holtikultura berkelanjuta. Jakarta: Kementrian Pertanian.

Felecia, Tessa VS. 2004. Peningkatan dayasaing industri melalui analisis biaya kualitas. Jurnal Teknik Industri 6(1):86-92.

Friska S. 2010. Value chain analysis (analisis rantai nilai) untuk keunggulan kompetitif melalui keunggulan biaya. Jurnal Ekonom 13(1):38-44.

Handayati W. 2013. Perkembangan pemulian mutasi tanaman hias di Indonesia. Jurnal Ilmiah Aplikasi Isotop dan Radiasi 9(1):67-80.

Her AF, Endang S, Siti NR. 2013. Indentifikasi karakteristik dan fungsi tanaman untuk taman rumah didataran medium dan dataran rendah. Vegetalika 1(1):1-12.

Kaplinsky R. 2000. Globalisation and unequalisation: What can be learned from value chain analysis? Journal of Development Studies 37(2):117-146. https://doi.org/10.1080/713600071.

Las I. 2007. Pembingkaian Diskusi Panel dan Penelitian Konsorsium Perubahan Iklim. Bogor: Badan Litbang Pertanian.

Mangold G, Faulds D. 2009. Social media: the new hybrid elemen of the promotion mix. Sciene Direct 52 (1):357-365. https://doi.org/10.1016/j. bushor.2009.03.002.

Mujilahwati S. 2014. Diagnosa penyakit tanaman hias menggunakan metode certainty factor berbasis WEB. Jurnal TeknikA 6(2):585-591.

Nayantakaningtyas JS, Daryanto HK. 2012. Dayasaing dan strategi pengembangan minyak sawit Indonesia. Jurnal Manajemen \& Agribisnis 9(3):194-201.

Nurmalinda D, Yani A. 2009. Preferensi konsumen hotel terhadap bunga potong gerbera. Jurnal Holtikultura 19(4):450-458.

Porter ME. 1985. Competitive Advantage - Creating a Sustaining Superior Performance. New York: The Free Press.

Ratih MK, Anas MF, Achmad C. 2012. Daya saing PT Benar Flora Utama berdasarkan aktivitas rantai nilai florikultura. Jurnal Manajemen \& Aggribisnis 9(3): 146-153.

Sari OD. 2008. Penggunaan saaluran komunikasi dan sikap petani tanaman hias tentang prospek bisnis anthurium (Anthurium sp) di Kecamatan Ngargoyoso Kabupaten Karanganyar. Agritexts 1(4): 1-15. 
Supranto J. 2003. Metode Riset, Aplikasinya dalam Pemasaran, Edisi 7. Jakarta: Rineka Cipta, Jakarta.

Sutedi. 2011. Rancang bangun sistem layanan terpadu tanaman hias berbasis Web. Jurnal Ilmiah ESAI
5(3):1-14.

Wisdaningrum O. 2013. Analisis rantai nilai (value chain) dalam lingkungan internal perusahaan. Analisa 1(1): 40-48. 